\title{
$\$$ Research Square

\section{Prevalence of Dengue Virus, Chikungunya and Zika Infection in Blood Donors of Northern of Brazil}

\section{Leticia Martins Lamarão}

Foundation Center for Hemotherapy and Hematology of Pará (HEMOPA)

Angelita Silva Miranda Corrêa

Foundation Center for Hemotherapy and Hematology of Pará (HEMOPA)

Renata Bezerra Hermes de Castro

Foundation Center for Hemotherapy and Hematology of Pará (HEMOPA)

Carlos Eduardo de Melo Amaral

Foundation Center for Hemotherapy and Hematology of Pará (HEMOPA)

\section{Patricia Danin Jordão Monteiro}

Foundation Center for Hemotherapy and Hematology of Pará (HEMOPA)

\section{Mauricio Koury Palmeira}

Foundation Center for Hemotherapy and Hematology of Pará (HEMOPA)

\section{Luane Nascimento Lopes}

Foundation Center for Hemotherapy and Hematology of Pará (HEMOPA)

\section{Angela Neves Oliveira}

Foundation Center for Hemotherapy and Hematology of Pará (HEMOPA)

\section{Maria Salete Maciel de Lima}

Foundation Center for Hemotherapy and Hematology of Pará (HEMOPA)

Rommel Rodríguez Burbano ( $\nabla$ rommel@ufpa.br)

Cytogenetics Human Laboratory, Biological Sciences Institute, Federal University of Pará

\section{Research Article}

Keywords: Prevalence, Dengue virus, infection, blood donors, Brazil, non-epidemic periods, symptomatic or asymptomatic

Posted Date: July 13th, 2021

DOI: https://doi.org/10.21203/rs.3.rs-600092/v2

License: (c) (i) This work is licensed under a Creative Commons Attribution 4.0 International License. Read Full License 


\section{Abstract}

We identified the prevalence of infection by the Dengue virus, Chikungunya and Zika in blood donors in epidemic and non-epidemic periods in the State of Pará, in Northern Brazil, we classify the donors (symptomatic or asymptomatic) and the possibility of this screening being carried out in a sample pool.

\section{Introduction}

The global increase in reemerging pathogens such as the Dengue virus (DENV), the Zika virus (ZIKV) and the Chikungunya virus (CHIKV) poses a threat to public health and the safety of the blood supply. All three pathogens are viruses transmitted by arthropods (arboviruses), mainly by Aedes aegypti [1]. These arboviruses have been reported over the years as constant threats to the human population, including recipients of blood transfusions, considering the high occurrence of asymptomatic cases and the fact that the presence of viremia precedes the onset of symptoms, so it is possible that infected blood donors act as a source of dissemination $[2,3]$.

We identified the prevalence of infection by the DENV, CHIKV and ZIKAV viruses in blood donors. 22,291 thousand donations raised by the Hematology and Hemotherapy Foundation of the State of Pará (HEMOPA), located in the city of Belém, which supports blood transfusion in Northern Brazil, were investigated.

\section{Methods}

In the period from $01 / 06 / 2018$ to $06 / 30 / 2020$, donors referred for blood collection were included in this research. This survey was carried out in accordance with the guidelines and norms of the Declaration of Helsinki. All research participants signed an informed consent form.

The samples were processed for automated nucleic acid extraction and purification according to the routine of the Nucleic Acid Test Laboratory (NAT) of Foundation Center for Hemotherapy and Hematology of Pará. The genetic material was extracted from a pool of four samples and underwent detection of DENV RNA (DENV 1, DENV 2, DENV 3 and DENV 4), ZIKAV and CHIKV using the One-Step Reverse Transcription Polymerase Chain Reaction (RT-PCR) technique, in a multiplex assay, using custom primers and probes.

\section{Results And Discussion}

In the study region, the first semester coincides with the rainy season and is considered seasonally epidemic for arboviruses and contributes significantly to the proliferation and development of Aedes aegypti [4]. One donor was found positive for CHIKV and one for DENV. CHIKV was found in a non-epidemic period and had an estimated prevalence of $0.02 \%$, which suggests that in non-epidemic periods, the chances of blood donors being able to transmit the virus, as they are asymptomatic or symptomatic, after donation, may be increased. DENV in an epidemic period with an annual prevalence of $0.01 \%$. Both prevalence's match or are higher than those found for the Hepatitis $C$ virus $(0.01 \%)$ and for the Hepatitis $B$ virus $(0.02 \%)$ in the study region (Table 1$)$. The detection of a positive case of DENV was found in the first 
semester of 2019, the period of greatest circulation of the vectors of the disease, and the period in which almost all cases occur in Brazil [5], suggesting attention in relation to this agent.

As for CHIKV in 2009, during an epidemic in a province in Thailand, a prevalence of $0.03 \%$ was found in blood donors, such as our study (6). So far, in the world literature, it has not been possible to predict transfusion transmission of this virus. DENV is an agent recognized as a threat to transfusion safety (7) as examples of studies carried out in other countries, including Brazil, where the transmission of blood transfusion with recipients in conditions of development is known to worsen the disease, compromising the primary treatment that the patient was receiving $[1,8]$.

As for ZIKAV, a systematic review found a prevalence of $0.85 \%$ of the virus in blood donors, although the development of apparent symptoms of the disease by ZIKAV in blood component containers has not been proven [8]. As far as we know, there are no descriptions of prevalence in the northern region of Brazil and, in this study, we did not detect this virus in blood donors. Positive donors for DENV and CHIKV were contacted by the project team and after clinical evaluation were classified as symptomatic after donation, however, both had mild symptoms such as mild fever, malaise, body aches, tiredness and both did not seek medical attention. at the time of donation. In this research, blood donations positive for DENV and CHIKV had no recipients.

The positive DENV and CHIKV samples were simulated in different sample pool quantities, up to the amount of 14 samples in the pool (Table 2). Was observed that if the DENV positive sample had been carried out within a plasma pool of 14 donation samples, it would have been detected automatically in the system protocol, however even in a pool of 20 samples it could be detected by the operator of the device, given that there was a curve growth (amplification of viral CDNA). As for CHIKV, it was observed that even if this sample were composing a pool of 20 plasma samples, it would have been detected automatically by the system protocol.

We conclude the need for continuous monitoring of research for ZIKAV and CHIKV and there is a need to include a continuous and mandatory molecular screening test for the four subtypes of DENV in the routine of blood centers, preventing this agent from being transmitted to recipients of blood components, and that special groups of immunosuppressed receptors may die.

\section{Abbreviations}

Foundation Center for Hemotherapy and Hematology of Pará (HEMOPA)

Dengue virus (DENV)

Zika virus (ZIKV)

Chikungunya virus (CHIKV)

Nucleic Acid Test Laboratory (NAT) 


\section{Declarations}

\section{Ethics approval and consent to participate}

The present research was approved by Ethics Committee of Ophir Loyola Hospital (CAAE 43610615.7.0000.5174).

\section{Consent for publication}

Not applicable.

All authors who participated in the research agree and consent to the publication of this manuscript.

\section{Availability of data and materials}

All experimental data and analysis results were stored in the NAT laboratory computer and all samples were stored in the HEMOPA Blood Bank, which are available to be reviewed. No public database is available to deposit our data. The datasets used and/or analysed during the current study are available from the corresponding author on reasonable request.

\section{Competing interests}

All authors declare that they have no conflicts of interest.

\section{Funding}

This study was supported by Brazilian funding agencies National Counsel of Technological and Scientific Development (CNPq; process 426916/2016-6 to L.M.L and process 301350/2019-1 to R.M.R.B.).

\section{Authors' contributions}

LML and RRB conceived and designed the study. $L M L, R R B, A S M C, L N L, A N O$ and MSML conducted the study and participated in the laboratory analysis. LML, RBHC CEMA, PDJM and RRB analysed the data. LML and RRB wrote the paper. All authors read and approved the final manuscript.

\section{Acknowledgements}

The authors are grateful with Fundação Amazônia Paraense de Amparo à Pesquisa (FAPESPA) by granting the university research scholarship to LNL, as well as Pró-Reitoria de Pesquisa e Pós-Graduação (PROPESP) of Universidade Federal do Pará (UFPA) for payment of the publication fees.

\section{References}


1. Stanley J, Chongkolwatana V, Duong PT, Kitpoka P, Stramer SL, Dung NTT, et al. Detection of dengue, chikungunya, and Zika RNA in blood donors from Southeast Asia. Transfusion. 2021;61:134-43.

2. Aghaie A, Aaskov J, Chinikar S, Niedrig M, Banazadeh S, Mohammadpour HK. Frequency of dengue virus infection in blood donors in Sistan and Baluchest an province in Iran. Transfus Apher Sci. 2014;50:59-62.

3. Musso D, Nhan T, Robin E, Roche C, Bierlaire D, Zisou K, et al. Potential for Zika virus transmission through blood transfusion demonstrated during an outbreak in French Polynesia, November 2013 to February 2014. Euro Surveill. 2014;19:20761.

4. Xavier LL, Honório NA, Pessanha JFM, Peiter PC. Analysis of climate factors and dengue incidence in the metropolitan region of Rio de Janeiro, Brazil. Plos One. 2021;16:e0251403.

5. Viana DV, Ignotti, E. The ocurrence of dengue and weather changes in Brazil: A systematic revie. Rev Bras Epidemiol. 2013;16,240-56.

6. Appassakij H, Promwong C, Rujirojindakul P, Wutthanarungsan R, Silpapojakul K. The risk of blood transfusion-associated Chikungunya fever during the 2009 epidemic in Songkhla Province, Thailand. Transfusion. 2014;54:1945-52.

7. Stramer SL. Current perspectives in transfusion-transmitted infectious diseases: emerging and reemerging infections. ISBT Sci Ser. 2014;9:30-6.

8. Levi JE, Nishiya A, Félix AC, Salles NA, Sampaio LR, Hangai F, Sabino EC, Mendrone A Jr. Real-time symptomatic case of transfusion-transmitted dengue. Transfusion. 2015;55:961-964.

9. Liu R, Wang X, Ma Y, et al. Prevalence of Zika virus in blood donations: a systematic review and metaanalysis. BMC Infect Dis. 2019;19:590.

\section{Tables}

Table 1. Donations investigated for DENV, ZIKAV and CHIKV and the prevalence found according to the period classification (epidemic and non-epidemic) and the half-yearly prevalence found during the study period.

\begin{tabular}{|c|c|c|c|c|c|c|c|}
\hline \multicolumn{2}{|c|}{ Classification } & \multicolumn{2}{|l|}{2018} & \multicolumn{2}{|l|}{2019} & \multicolumn{2}{|l|}{2020} \\
\hline & & $\begin{array}{l}\text { Number } \\
\text { donations }\end{array}$ & Prevalence & $\begin{array}{l}\text { Number } \\
\text { donations }\end{array}$ & Prevalence & $\begin{array}{l}\text { Number } \\
\text { donations }\end{array}$ & Prevalence \\
\hline \multirow[t]{2}{*}{$\begin{array}{l}\text { 1st } \\
\text { period. }\end{array}$} & $\begin{array}{l}1 \mathrm{st} \\
\text { Semester }\end{array}$ & 827 & - & 5.039 & $0,02 \% \#$ & - & - \\
\hline & $\begin{array}{l}\text { 2nd } \\
\text { Semester }\end{array}$ & 5.294 & $0,02 \% *$ & 5.177 & - & 5.554 & - \\
\hline Total & & 6.121 & $0,02 \% *$ & 10.216 & $0,01 \% \#$ & 5.954 & - \\
\hline
\end{tabular}

${ }^{*}$ CHIKV, \#DENV 
Table 2. Identification and detection values of the positive sample for DENV and CHIKV in different quantitative sample pools.

\begin{tabular}{|llllllllll|}
\hline \multicolumn{8}{|c|}{ AVERAGE DETECTION VALUES } \\
\hline Number of Pooled Samples & $\mathbf{6}$ & $\mathbf{8}$ & $\mathbf{1 0}$ & $\mathbf{1 2}$ & $\mathbf{1 4}$ & $\mathbf{1 6}$ & $\mathbf{1 8}$ & $\mathbf{2 0}$ \\
\hline DENGUE & 23,7 & 24,2 & 25,4 & 28,8 & 28,5 & ND* & ND* & ND* \\
\hline CHIKUNGUNYA & 22,8 & 23,1 & 23,8 & 24,2 & 24,1 & 24,4 & 24,5 & 25,0 \\
\hline
\end{tabular}

ND: not detected; * Presence of a curve below the detection limit 